\title{
MODEL KEBIJAKAN MONETER DALAM PEREKONOMIAN TERBUKA UNTUK INDONESIA
}

\author{
Umar Juoro'
}

\begin{abstract}
This paper analyze the impact of foreign policy (the Fed) on Indonesia's monetary economy, focusing on the attention is also to the fund rate. An empirical model of VAR (Vector Auto Regression) is developed to capture the impact of increase in fund rate to Indonesia's monetary sector. The system of equations covers central bank policy rate, lending rate, inflation, real effective rate (REER), and the output growth. The result shows that the increase of fund rate tended to push Bank Indonesia to increase his policy rate, hence the lending rate. On the other side, positive shock of foreign fund rate lower inflation and output growth, and appreciate the Real Effective Exchange Rate with lag.
\end{abstract}

Keyword: monetary policy, lending rate, inflation, exchange rate.

JEL Classification: E52, F41

1 Author is Chairman of Supervisory Board of Bank Indonesia (BSBI) and is Senior Economist at CIDES (Center for Information and Development Studies). Corresponding author: juoro@indo.net.id. We thank to Abdul Manap Pulungan for his excellent research assistance. 


\section{PENDAHULUAN}

Kebijakan moneter di Indonesia fokus pada inflasi. Sekalipun demikian aspek pertumbuhan tetap menjadi perhatian. Dengan ekonomi yang terbuka kebijakan moneter juga berimplikasi pada nilai tukar (exchange rate). Karena itu kebijakan menaikkan atau menurunkan BI rate berimplikasi tidak saja pada inflasi, tetapi juga pada pertumbuhan, dan nilai tukar.

Perkembangan utama sektor moneter di Indonesia dalam periode 2000-2013 dapat digambarkan dalam lima pengamatan (stylized facts): Pertama, dipergunakannya BI rate sebagai instrumen kebijakan moneter mulai pada bulan Juli 2005, yang juga menetapkan sasaran kebijakan moneter adalah inflasi. Kedua, inflasi tinggi pada tahun 2005 setelah kenaikan harga BBM lebih sekitar 130\%, BI menaikkan BI rate cukup tinggi menjadi 12,75\% pada bulan Desember 2005. Ketiga, krisis finansial global pada bulan Desember tahun 2008 membuat BI kembali menaikkan BI rate pada tingkatan 9,50\%, setelah penurunan BI rate dilakukan pada periode 2006-2007.

Keempat, kebijakan moneter longgar, dengan BI rate terendah yang diikuti oleh bunga pinjaman terendah dalam sejarah ekonomi Indonesia pada periode 2010-2012. Kelima, peningkatan BI rate kembali menanggapi rencana pengurangan stimulus (tapering) dari the Fed pada bulan Juni tahun 2013. Keenam, perkembangan bunga pinjaman mengikuti kenaikan $\mathrm{BI}$ rate dengan cepat, dengan penurunan bunga pinjaman yang sangat lambat ketika $\mathrm{Bl}$ rate diturunkan.

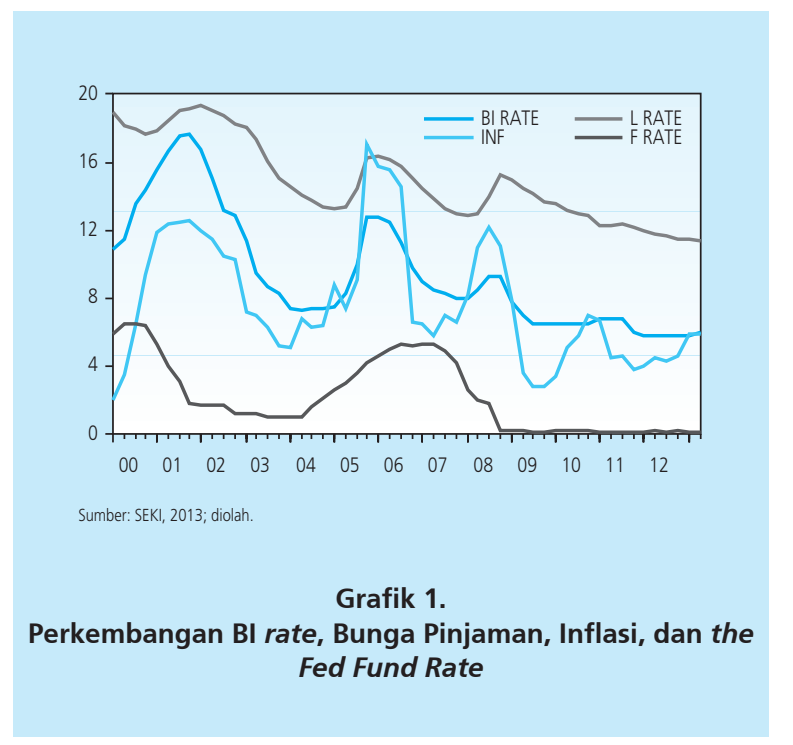




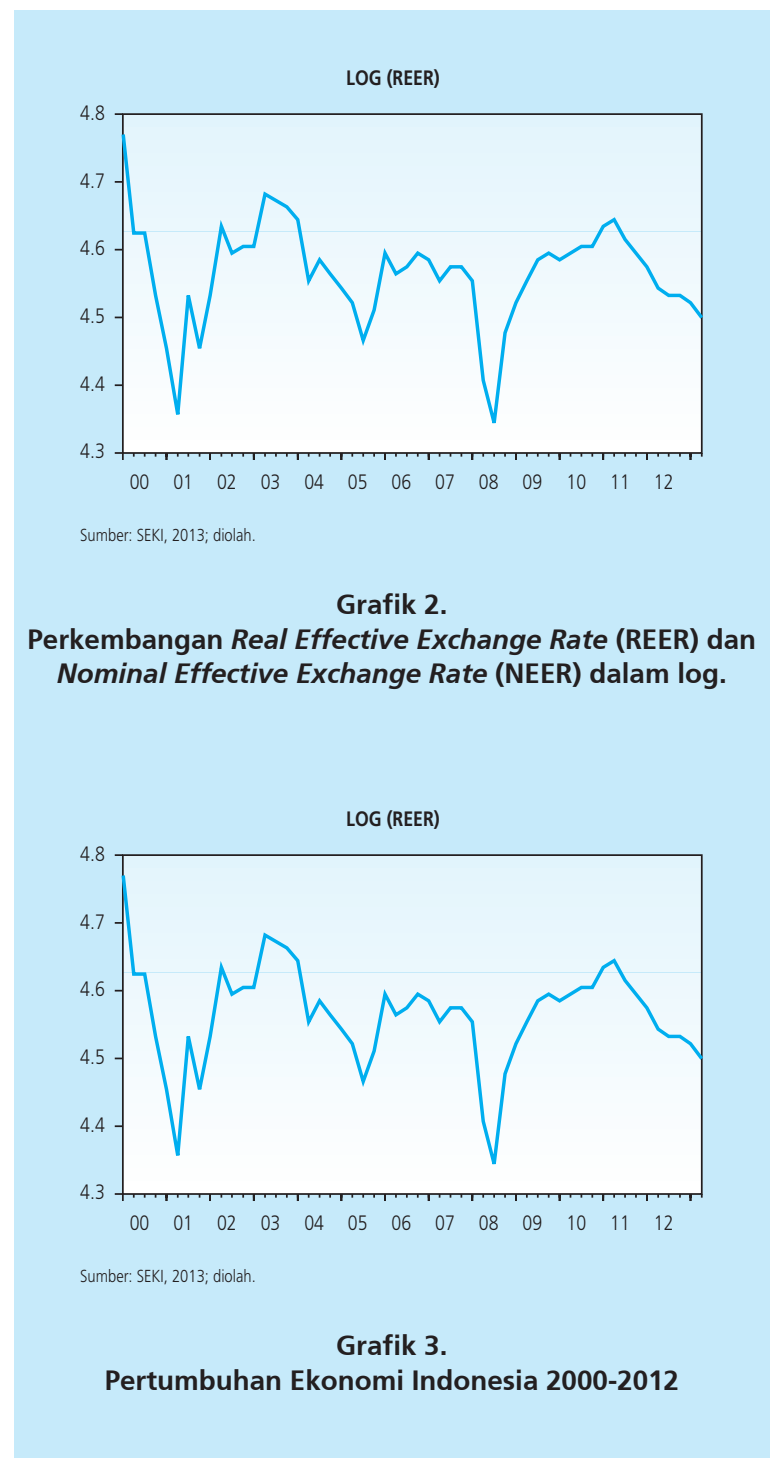

Perkembangan nilai tukar riil (REER) sangat terkait dengan inflasi dan fund rate. Pada saat inflasi dan fund rate tinggi, REER mengalami depresiasi, seperti pada tahun 2001, dan 2008. Pada saat inflasi rendah dan fund rate rendah, REER mengalami apresiasi, seperti pada tahun 2009-2012 (Gambar 1).

Dalam kaitannya dengan inflasi, pertumbuhan ekonomi yang tinggi berkesesuaian dengan tingkat inflasi yang rendah. Tingkat pertumbuhan yang tinggi ini juga terjadi saat fund rate dan $\mathrm{BI}$ rate rendah (juga fund rate) rendah, seperti yang terjadi pada tahun 2000, 2004, dan tahun 2010. Sebaliknya, pertumbuhan menurun tajam pada saat inflasi tinggi, BI rate (dan fund rate) tinggi, seperti pada tahun 2001, dan 2008 (Gambar 3). 
Gambaran empiris di atas menunjukkan bahwa kebijakan moneter yang dilakukan oleh Bank Indonesia, memiliki pengaruh terhadap perekonomian. Dengan demikian mengukur dampak kebijakan moneter tersebut perlu dilakukan dengan mempertimbangkan berbagai faktor di luar hubungan korelatif 2 (dua) arah di atas. Inilah yang mendasari penelitian yang dituangkan dalam paper ini.

Bagian ketiga dari paper ini mengulas model teoretikal dari kebijakan moneter dalam ekonomi terbuka, dengan spesifikasi yang disesuaikan untuk perekonomian Indonesia. Model ini mengadopsi kekakuan harga (price rigidities), penyesuaian harga membutuhkan waktu, Taylor's rule, dimana kebijakan moneter sekalipun sasaran utamanya adalah inflasi tetapi juga mempertimbangkan pertumbuhan, dan perkembangan teknologi bersifat endogenus dalam meningkatkan produktivitas melalui penurunan biaya marginal. Dengan metoda komputasional mempergunakan program komputer MATLAB, maka dapat diperoleh IRF dari model teoritis tersebut, untuk dikonfrontasikan dengan model empiris VAR yang diulas pada bagian keempat. Bagian kelima menyajikan hasil dan analisis, sementara bagian keenam memberikan kesimpulan dan implikasi kebijakan.

\section{TEORI}

\subsection{Set Up Model}

Untuk mengembangkan model kebijakan moneter yang menangkap analisis empiris tersebut dikembangkan model kebijakan moneter dalam ekonomi terbuka yang diadopsi dari Monacelli (2005) selanjutnya dimodifikasi oleh Tai Kuang Ho (2008) dengan menyesuaikannya dengan karakteristik ekonmi Indonesia.

Dalam model teoritis ini rumah tangga memaksimalkan fungsi utilitas sebagai berikut:

$$
\mathrm{E}_{0} \sum_{\mathrm{t}=0}^{\mathrm{t}=\infty} \beta^{\mathrm{t}} \mathrm{U}\left(\mathrm{C}_{\mathrm{t}}\right), \mathrm{N}_{\mathrm{t}}
$$

dimana Nt adalah waktu kerja, Ct adalah indeks komposit konsumi. Rumah tangga dihadapkan pada memaksimalkan utilitas dengan batasan anggaran (budget constraint) upah, portofolio, dan transfer pajak yang lebih besar daripada belanja barang domestik dan impor. Sedangkan perusahaan menghadapi harga yang kaku (price rigidities) sebagaimana diformulasikan oleh Calvo (1983). Spesifikasi selanjutnya adalah inflasi domestik, REER, interest rate cover parity, dan teknologi. Fungsi produksi diberikan sebagai berikut untuk $a_{t}=\log \left(A_{t}\right)$ diasumsikan mengikuti proses $A R(1)$

$$
Y_{i}(j)=A_{i} N_{t}(j)
$$


Untuk memperoleh kesimbangan dinamis model ekonomi kecil terbuka dengan nilai tukar fleksibel (small open economy with flexible exchange rate) maka perlu menurunkan 22 persamaan dengan 22 variabel. Persamaan tersebut adalah untuk ekonomi domestik terdiri dari market clearing, terms of trade-REER, Philipps curve, marginal cost, complete market (menghubungkan domestik dan internasional), uncovered interest parity, kebijakan moneter (Taylor's rule), inflasi produser, output gap, kejutan produktivitas, kejutan moneter, dan kejutan stabilisasi nilai tukar. Sementara itu, untuk ekonomi internasional spesifikasinya adalah fungsi permintaan agregat, kurva penawaran agregat, biaya marjinal, kebijakan moneter (Taylor's rule), output gap, kejutan produktivitas, dan kejutan moneter.

Seluruh persamaan dispesifikasi dalam bentuk log linier yang menunjukan pergeserannya dari keadaan steady state, di bawah ini (Tanda $\left(^{*}\right)$ menunjukkan luar negeri).

Suku bunga domestic:

$r_{t+1}=r_{t}$;

Domestic term of trade

$\mathrm{S}_{\mathrm{t}+1}=\mathrm{S}_{\mathrm{t}}$;

Suku bunga luar negeri (foreign)

$r_{\mathrm{St}+1}=r_{\mathrm{st}}$;

Domestic production shock

$z_{t+1}=\rho z_{t} ;$

Foreign production shock

$\mathrm{ZS}_{\mathrm{t}+1}=\rho z \mathrm{~S}_{\mathrm{t}}$;

Domestic monetary shock

$\mathrm{zm}_{\mathrm{t}+1}=\rho z \mathrm{~m}_{\mathrm{t}}$;

Foreign monetary shock

$z \mathrm{~ms}_{\mathrm{t}+1}=\rho z \mathrm{~ms}_{\mathrm{t}+1}$ ； 
Foreign exchange policy shock

$z q_{t+1}=\rho z q_{t}$

Market clearing condition

$(1-\gamma) c_{t}=y_{t}-(2-\gamma) \gamma n s_{t}-\gamma y_{t} ;$

Real exchange rate related to term of trade

$q_{t}=(1-\gamma) s_{t} ;$

Forward looking Philips curve

$\pi_{1+\mathrm{t}}=\beta \mathrm{E}_{\mathrm{t}}\left\{\pi_{\mathrm{H}, \mathrm{t}+\mathrm{1}}\right\}+\lambda_{\mathrm{H}} \cdot \mathrm{mc}_{\mathrm{t}}$;

Real marginal consumption rates of domestic goods

$m c_{t}=\sigma C_{t}+\varphi Y t+\gamma s_{t}-(1+\varphi) z_{t}$

Kaitan antara konsumsi domestik dan luar negeri

$C t=y t *+1 / \sigma[(1-\gamma) s t]$

Interest parity rate in term of interest rate differential and real exchange rate $\left[r_{t}-E_{t}\left\{\pi_{t+1}\right\}\right]-\left[r_{t}-E_{t}\left\{\pi_{t+1}^{*}\right\}\right]=E_{t}\left\{\Delta \Sigma_{t+1}\right\}$

Monetary policy based on Taylor rule

$r_{t}=\rho_{t} r_{t-1}+(1-\rho t)\left(\varphi_{\pi} \pi_{t}+\varphi_{x} x t\right)+z m, t$;

Inflasi:

$\pi_{t}=\pi_{h, t}+\gamma \Delta S t$;

Output gap

$X_{t}=E_{t}\left\{X_{t+1}\right\}-\frac{W}{\sigma}\left[r_{t}-E_{t}\left\{\pi_{H, t+1}\right\}-{ }_{r r t}^{-}\right]$; 
Foreign aggregate demand

$Y^{*}{ }_{t}=E_{t}\left\{Y^{*}{ }_{t+1}\right\}-\frac{1}{\sigma}\left[r^{*}{ }_{t}-E_{t}\left\{\pi_{t+1}^{*}\right\}\right]$;

Foreign aggregate supply

$\pi^{*}{ }_{t}=\beta E_{t}\left\{\pi^{*}{ }_{t+1}\right\}+\frac{(1-\theta)(1-\beta \theta)}{\theta} m c^{*}{ }_{t}$;

Foreign monetary policy (Taylor Rule)

$\mathrm{mc}_{\mathrm{t}}^{*}=(\sigma+\varphi) \mathrm{Yt}^{*}-(1+\varphi) \mathrm{Zt}^{*}$;

Foreign natural rate of interest

$r_{t}^{*}=\rho_{t}{ }^{*} r_{t-1}+\left(1-\rho_{t}^{*}\right)\left(\varphi_{\pi} \pi_{t}^{*}+\varphi_{x} X_{t}^{*}\right)+Z^{*}{ }_{m, t}$;

Foreign output gap

$X_{t}^{*}=Y_{t}^{*}-\left[\frac{1+\varphi}{\sigma+\varphi}\right] Z_{t}^{*}$;

\subsection{Kalibrasi Model}

Kalibrasi model menggunakan besaran parameter yang disajikan pada Tabel 1. Dasar kalibrasi untuk setiap parameter tersebut mengacu pada hasil estimasi diluar model ini, dan juga mengacu pada berbagai studi-studi sebelumnya. 


\begin{tabular}{c|c|l} 
Nimbol & \multicolumn{1}{c}{$\begin{array}{c}\text { Tabel 1 } \\
\text { Nilai Parameter }\end{array}$} \\
\hline B & Nilai & \\
\hline$\Sigma$ & 0,99 & Discount factor \\
\hline A & 1 & Inverse elasticity of intertemporal substitution \\
\hline$\Phi$ & 1,5 & Elasticity of subs. Domestic and foreign good \\
\hline$\Phi$ & 1 & Elasticity of subst. of labor supply \\
\hline$\square \mathrm{H}$ & 1,$5 ; 0,5$ & Koefisien inflasi dan output gap dalam Taylor rule luar negeri \\
\hline$\square$ & 0,75 & Tingkat kekakuan harga \\
\hline$\Phi$ & 0,65 & Persistence parameter \\
\hline$\rho_{\mathrm{s}}$ & 0,1 & Kejutan (shock) produktivitas domestic \\
\hline$\square$ & 0,6 & Kejutan produktivitas luar negeri \\
\hline$\rho_{\mathrm{r}}$ & 0,3 & Bagian barang impor \\
\hline$\rho_{\mathrm{rs}}$ & 0,38 & Degree of interest rate smoothing domestic, Taylor rule, \\
\hline$\Phi_{\pi}$ & 0,8 & Degree of interest rate smoothing foreign, Taylor rule \\
\hline$\Phi_{\mathrm{x}}$ & 1,2 & Koefisien inflasi dalam Taylor rule domestik \\
\hline$\rho_{\mathrm{z}}$ & 0,35 & Koefisien output gap dalam Taylor rule domestik \\
\hline$\rho_{\mathrm{zs}}$ & 0,9 & Kejutan produktivitas domestik \\
\hline$\rho_{\mathrm{q}}$ & 0,9 & Kejutan produktivitas luar negeri \\
\hline & 0,6 & Kejutan stabilitas nilai tukar \\
\hline
\end{tabular}

\section{METODOLOGI}

Penelitian ini menggunakan model VAR yang mengasumsikan ekonomi Indonesia dapat dijelaskan dengan persamaan struktural sebagai berikut :

$$
A(L) Y_{t}=B(L) X_{t}+\varepsilon_{t}
$$

$\mathrm{A}(\mathrm{L})$ adalah matriks polinominal $\mathrm{n} \times \mathrm{n}$ dengan operator lag, dan $\mathrm{B}(\mathrm{L})$ adalah matriks polinominal $n \times k$ dengan operator lag. $Y_{t}$ adalah variabel endogenus yang terdiri dari $g_{t}$ adalah pertumbuhan ekonomi, $\pi_{t}$ adalah inflasi, $q_{t}$ adalah log (REER), $b_{t}$ adalah $B \mathrm{Bl}$ rate, dan $\mathrm{fr}_{\mathrm{t}}$ adalah fund rate. $X_{t}$ adalah $k \times 1$ vektor Eksogen variabel luar negeri (fund rate), $\varepsilon_{t}$ adalah vektor distribusi struktural $\mathrm{n} \times 1$, dimana $\operatorname{var}\left(\varepsilon_{t}\right)=\Omega$ yang merupakan matriks diagonal.

Untuk mengetahui implikasi dari kebijakan moneter di luar negeri (the Fed) terhadap ekonomi Indonesia, maka model VAR berikutnya adalah dalam bentuk orde pertama VAR yaitu: 


$$
A\left[\begin{array}{l}
g_{t} \\
\pi_{t} \\
q_{t} \\
b r_{t} \\
f r_{t}
\end{array}\right]=B\left[\begin{array}{l}
g_{t-1} \\
\pi_{t-1} \\
q_{t-1} \\
b r_{t-1} \\
f r_{t-1}
\end{array}\right]+\left[\begin{array}{c}
\varepsilon^{g} \\
\varepsilon^{\pi} \\
\varepsilon^{q} \\
\varepsilon^{d} \\
\varepsilon^{f}
\end{array}\right]
$$

Identifikasi model empiris dengan menetapkan batasan bahwa matriks A adalah lower triangular dengan unit diagonal elements. Karena $b r_{t}$ dan $\mathrm{fr}_{\mathrm{t}}$ muncul di bagian bawah sistem, strategi identifikasinya adalah bahwa inovasi dari BI rate $\left(\varepsilon_{t}{ }^{d}\right)$ dan inovasi fund rate $\left(\varepsilon_{t}{ }^{f}\right)$ berpengaruh pada variabel endogenus domestik dengan satu periode lag.

Batasan lainnya adalah bahwa dalam estimasi sistem VAR adalah $\mathrm{fr}_{\mathrm{t}}$ mengikuti simple univariate process $A R(1)$. Simple univariate process adalah dengan membuat batasan $A_{51}=B_{51}$ $=0$, untuk semua i tidak sama dengan 5. Tujuan mengadopsi batasan ini karena asumsi bahwa gangguan dari negara berkembang, dalam hal ini Indonesia, kecil sekali pengaruhnya pada negara besar seperti AS.

\section{HASIL DAN ANALISIS}

Hasil estimasi model disajikan pada Grafik 4. Panel a pada Grafik tersebut memperlihatkan kenaikan BI rate (25 bps) di atas steady state menyebabkan kenaikan bunga pinjaman sebesar 20 bps di atas steady state dan secara bertahap kembali ke keadaan steady state. Inflasi, pertumbuhan ekonomi menurun, dan secara bertahap kembali ke keadaan steady state. Inflasi kembali dalam dua triwulan dan REER dalam 7 triwulan ke keadaan steady state. ${ }^{2}$

Grafik 4(b) memperlihatkan kebijakan stabilisasi nilai tukar dapat dengan cepat menstabilkan inflasi, bunga pinjaman, dan nilai tukar kembali ke keadaan steady state hanya dalam dua triwulan, dan pertumbuhan ekonomi positif.

Grafik 4(c) memperlihatkan kenaikan fund rate yang diikuti oleh kenaikan BI rate menaikkan bunga pinjaman, menurunkan inflasi, menurunkan pertumbuhan, dan apresiasi REER. Nilai tukar kembali kepada keadaan steady state dalam waktu yang lebih panjang daripada jika hanya kenaikan BI rate saja, tidak ada kenaikan fund rate.

2 Dalam bab hasil dan analisis akan ditunjukkan bahwa hasil ini mirip dengan hasil model VAR yang digunakan. 

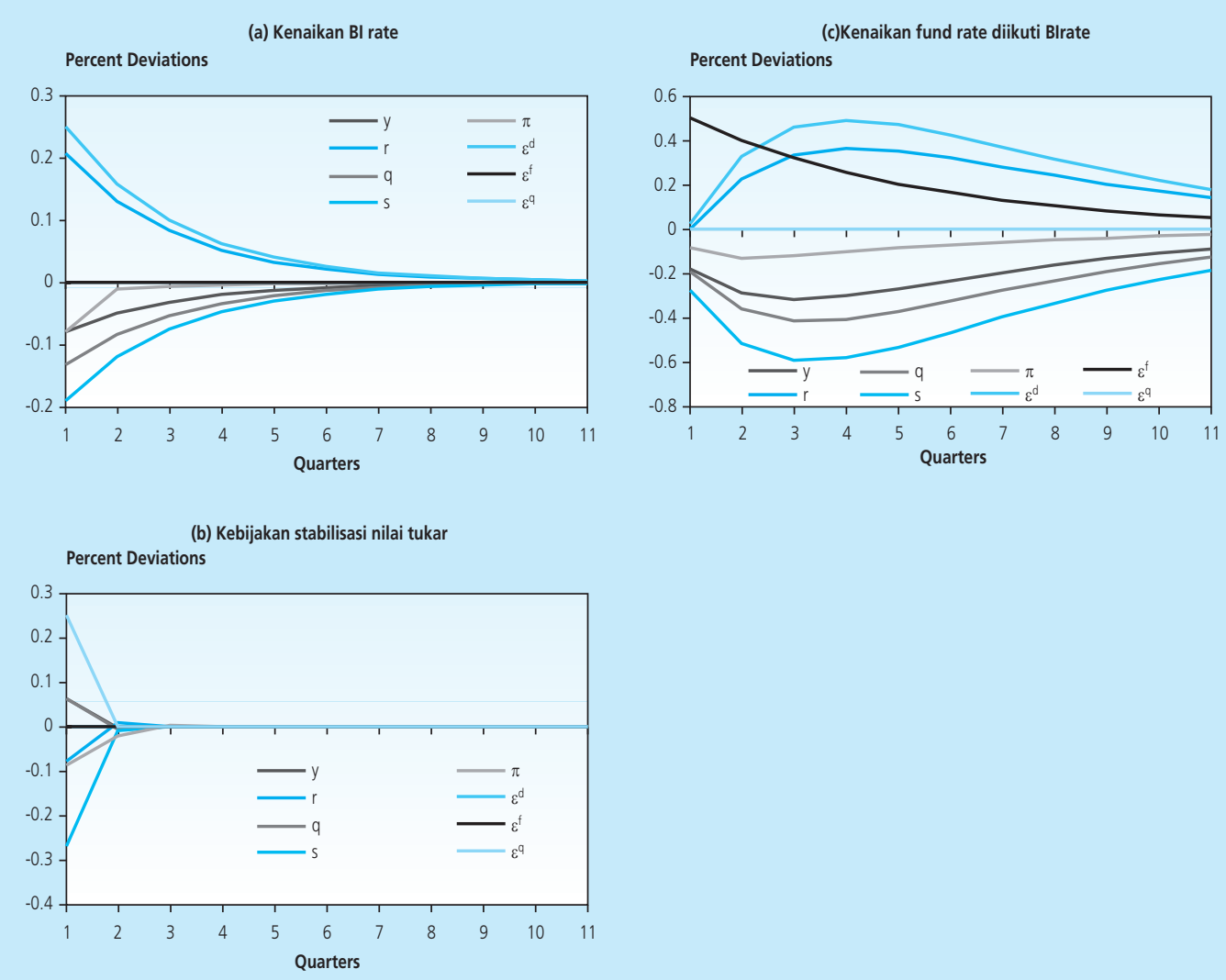

Sumber: Hasil Simulasi

\section{Grafik 4. Kebijakan Kenaikan BI rate dan fund rate dan Implikasinya terhadap Ekonomi dan Stabilisasi Kebijakan Nilai Tukar}

Grafik 5(a) memperlihatkan kebijakan moneter stimulatif dengan menurunkan BI rate (25 bps) dari keadaan steady state yang segera diikuti dengan penurunan bunga pinjaman, peningkatan inflasi, REER, dan pertumbuhan. Grafik $5(\mathrm{~b})$ memperlihatkan penurunan fund rate yang dikuti oleh penurunan BI rate meningkatkan pertumbuhan ekonomi domestik. Sementara itu bunga pinjaman, inflasi, dan REER mengalami peningkatan.

Grafik 5(c) memperlihatkan peningkatan produktivitas domestik meningkatkan pertumbuhan ekonomi lebih tinggi daripada penurunan BI rate. Inflasi dan bunga pinjaman menurun, sementera itu REER menguat. Gambar 5 (d) memperlihatkan peningkatan produktivitas di luar negeri berpengaruh negatif pada ekonomi domestik dengan menurunnya pertumbuhan. Sedangkan inflasi, bunga pinjaman, dan REER melemah. 

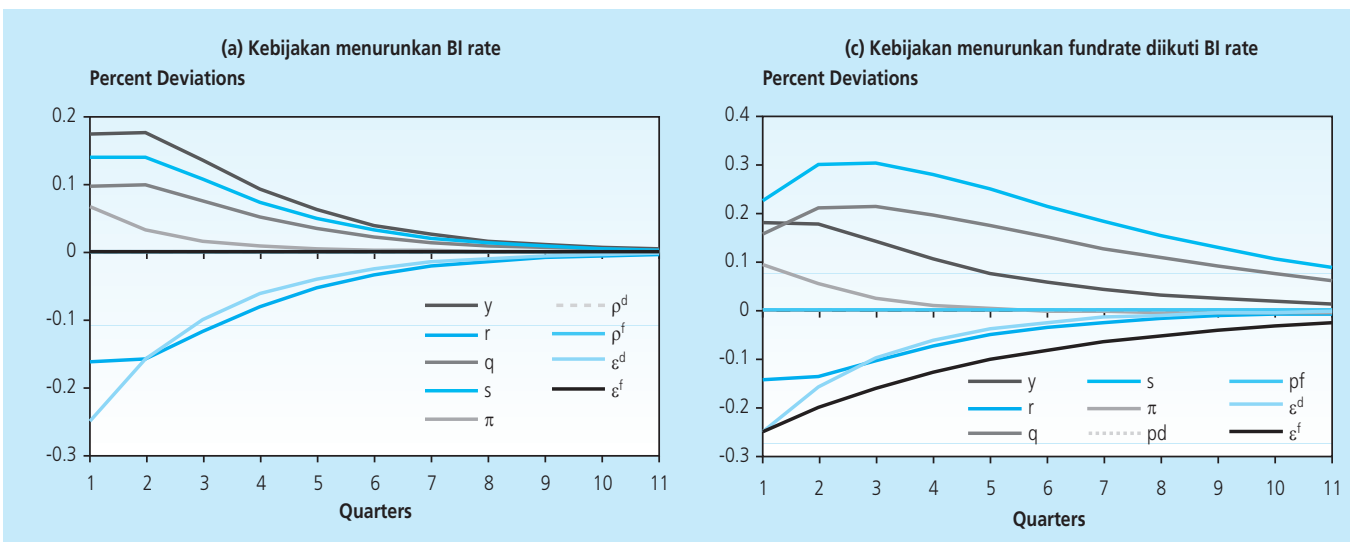

(b) Peningkatan produktivitas domestik Percent Deviations

(d) Peningkatan produktivitas di luar negeri Percent Deviations
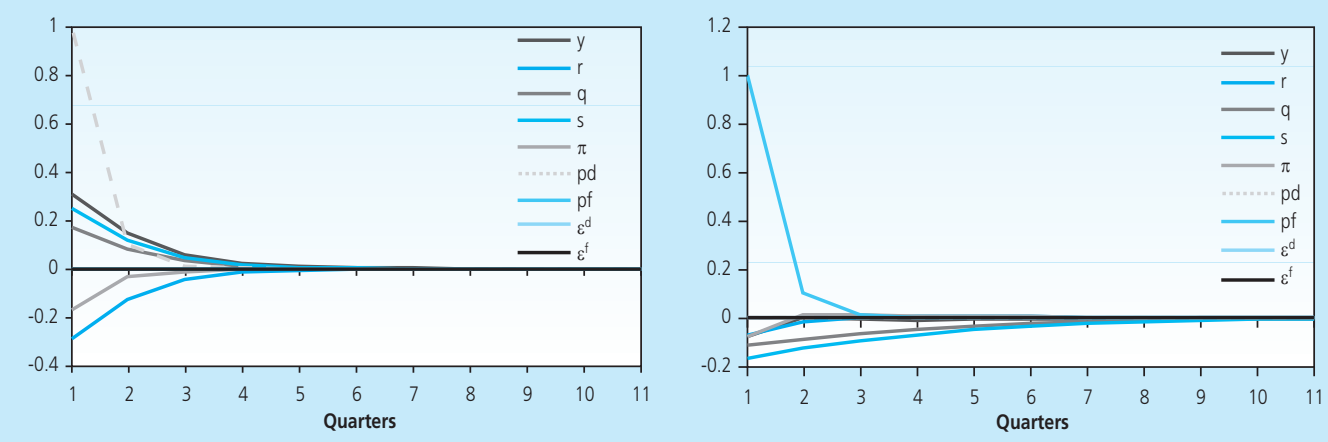

Sumber: Hasil Simulasi

Grafik 5. Dampak Stimulus Penurunan BI, Penurunan Fund Rate dan Dampak Kenaikan Produktivitas terhadap Perekonomian

\subsection{Impulse Response Function}

Grafik 6 menyajikan Impulse response function dari kejutan berupa kenaikan BI rate. Dari Grafik tersebut terlihat bahwa kenaikan BI rate diikuti oleh kenaikan bunga pinjaman (Irate). Kenaikan BI rate menurunkan inflasi (inf) hanya setelah tiga triwulan (lag) dan kembali pada keadaan steady state setelah delapan triwulan (lag). Kenaikan BI rate membuat REER mengalami apresiasi namun bersifat tidak strabil. Kenaikan BI rate menurunkan pertumbuhan ekonomi. Jadi kenaikan BI rate secara cepat diikuti oleh kenaikan bunga pinjaman dan menurunkan pertumbuhan ekonomi dengan menurunnya konsumsi masyarakat. Sedangkan penurunan inflasi dan penguatan mata uang membutuhkan waktu untuk efektif (lag) dan bersifat tidak stabil.

Sementara itu kenaikan fund rate segera diikuti oleh kenaikan BI rate, bunga pinjaman, dan penurunan inflasi (dengan lag). Kenaikan fund rate juga berimplikasi pada depresiasi REER dan penurunan pertumbuhan ekonomi (dengan lag). Namun dengan kenaikan BI rate, REER kemudian mengalami apresiasi (dengan lag). Hal ini dimengerti karena kenaikan fund rate diikuti oleh kenaikan BI rate yang berimplikasi pada variabel endogenus (Grafik 7). 
Response to Cholesky One S.D. Innovations \pm 2 S.E.
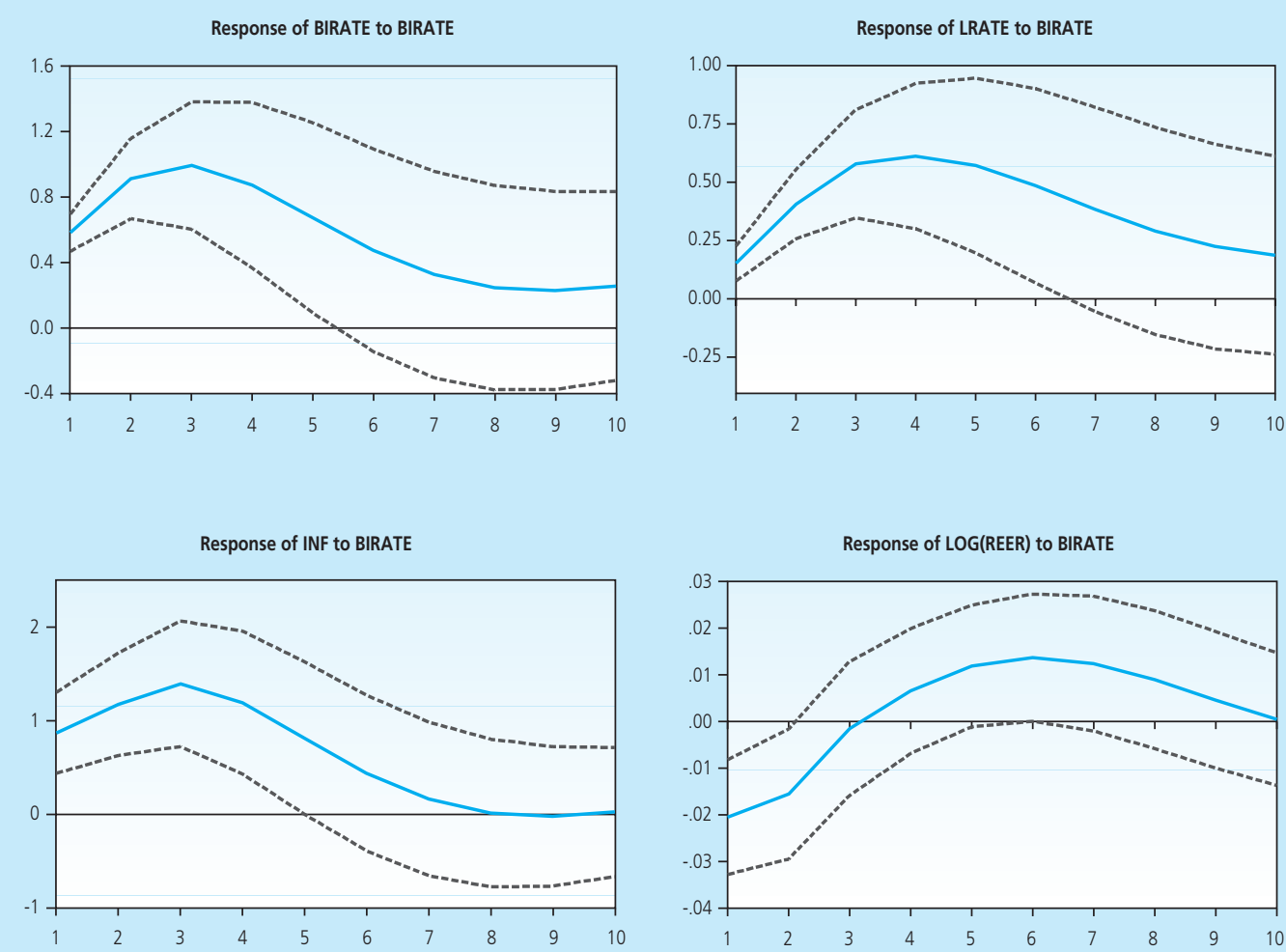

Response of GROWTH to BIRATE

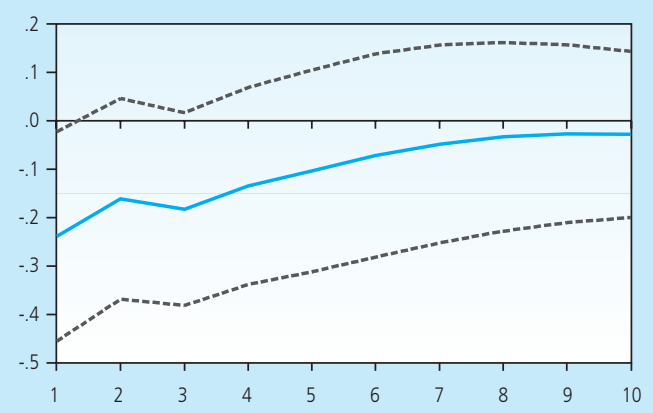

Grafik 6.

Respon terhadap Kenaikan BI rate dengan Variabel Eksogen Fund Rate 
Response to Cholesky One S.D. Innovations \pm 2 S.E.
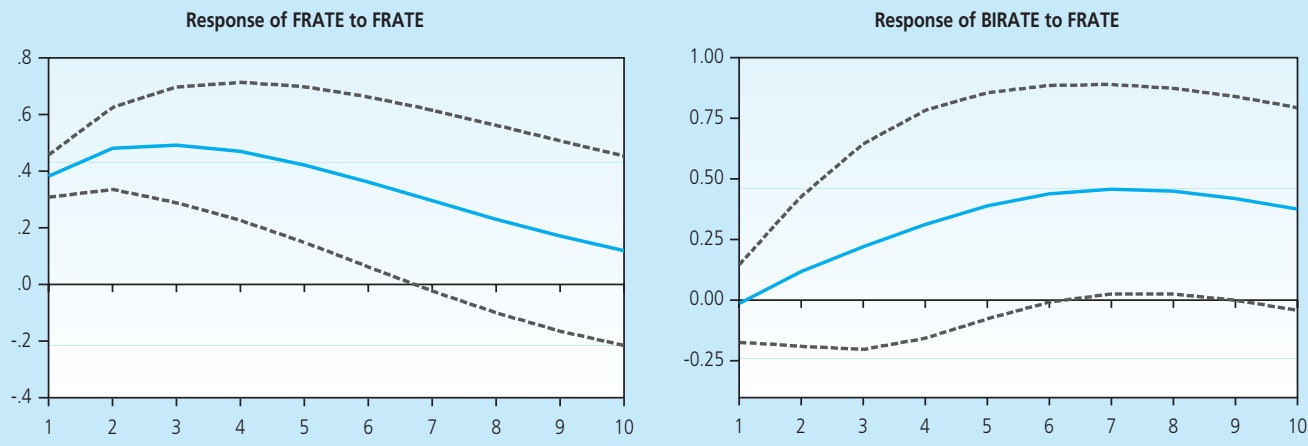

Response of LRATE to FRATE

Response of INF to FRATE
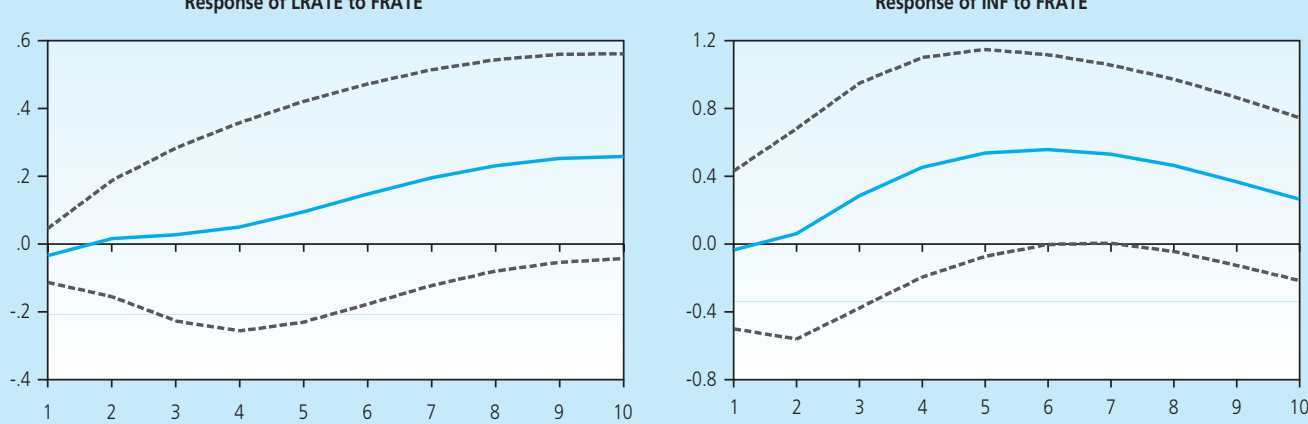

Response of LOG(REER) to FRATE

Response of GROWTH to FRATE
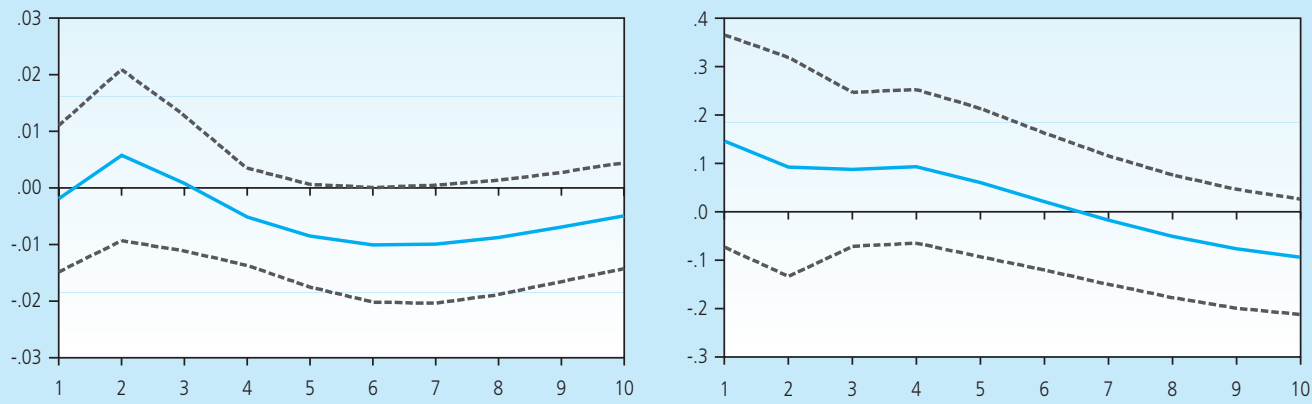

Grafik 7.

Respon terhadap Kenaikan Fund Rate 


\subsection{Granger Causality Test}

Untuk mengetahui variabel satu mempengaruhi variabel lainnya dilakukan Granger causality test (Tabel 2) Dari hasil estimasi, dengan milihat $t$-statistics tampak bahwa frate mempengaruhi BI rate, $\mathrm{BI}$ rate dan bunga pinjaman saling mempengaruhi, inflasi dan BI rate saling mempengaruhi, REER mempengaruhi BI rate, $\mathrm{BI}$ rate mempengaruhi pertumbuhan, fund rate mempengaruhi inflasi, fund rate mempengaruhi REER, REER mempengaruhi bunga pinjaman, REER dan pertumbuhan saling mempengaruhi, bunga pinjaman mempengaruhi pertumbuhan,

\begin{tabular}{|c|c|c|c|}
\hline \multicolumn{4}{|c|}{$\begin{array}{c}\text { Tabel } 2 \\
\text { Granger Causality Test }\end{array}$} \\
\hline Sample: 2000Q1 2013Q2 & & & \\
\hline \multicolumn{4}{|l|}{ Lags: 2} \\
\hline Null Hypothesis: & Obs & F-Statistic & Prob. \\
\hline $\begin{array}{l}\text { FRATE does not Granger Cause BIRATE } \\
\text { BIRATE does not Granger Cause FRATE }\end{array}$ & 52 & $\begin{array}{l}3.21691 \\
0.08269\end{array}$ & $\begin{array}{l}0.0490 \\
0.9208\end{array}$ \\
\hline $\begin{array}{l}\text { LRATE does not Granger Cause BIRATE } \\
\text { BIRATE does not Granger Cause LRATE }\end{array}$ & 52 & $\begin{array}{l}2.50859 \\
9.70918\end{array}$ & $\begin{array}{l}0.0922 \\
0.0003\end{array}$ \\
\hline $\begin{array}{l}\text { INF does not Granger Cause BIRATE } \\
\text { BIRATE does not Granger Cause INF }\end{array}$ & 52 & $\begin{array}{l}3.09954 \\
7.98482\end{array}$ & $\begin{array}{l}0.0544 \\
0.0010\end{array}$ \\
\hline $\begin{array}{l}\text { LOG(REER) does not Granger Cause BIRATE } \\
\text { BIRATE does not Granger Cause LOG(REER) }\end{array}$ & 52 & $\begin{array}{l}7.39518 \\
1.38538\end{array}$ & $\begin{array}{l}0.0016 \\
0.2603\end{array}$ \\
\hline $\begin{array}{l}\text { GROWTH does not Granger Cause BIRATE } \\
\text { BIRATE does not Granger Cause GROWTH }\end{array}$ & 52 & $\begin{array}{l}1.10661 \\
3.08633\end{array}$ & $\begin{array}{l}0.3391 \\
0.0550\end{array}$ \\
\hline $\begin{array}{l}\text { LRATE does not Granger Cause FRATE } \\
\text { FRATE does not Granger Cause LRATE }\end{array}$ & 52 & $\begin{array}{l}0.16020 \\
1.89368\end{array}$ & $\begin{array}{l}0.8524 \\
0.1618\end{array}$ \\
\hline $\begin{array}{l}\text { INF does not Granger Cause FRATE } \\
\text { FRATE does not Granger Cause INF }\end{array}$ & 52 & $\begin{array}{l}0.57138 \\
3.50136\end{array}$ & $\begin{array}{l}0.5686 \\
0.0382\end{array}$ \\
\hline $\begin{array}{l}\text { LOG(REER) does not Granger Cause FRATE } \\
\text { FRATE does not Granger Cause LOG(REER) }\end{array}$ & 52 & $\begin{array}{l}0.26765 \\
2.93240\end{array}$ & $\begin{array}{l}0.7663 \\
0.0631\end{array}$ \\
\hline $\begin{array}{l}\text { GROWTH does not Granger Cause FRATE } \\
\text { FRATE does not Granger Cause GROWTH }\end{array}$ & 52 & $\begin{array}{l}1.10998 \\
1.89279\end{array}$ & $\begin{array}{l}0.3380 \\
0.1620\end{array}$ \\
\hline $\begin{array}{l}\text { INF does not Granger Cause LRATE } \\
\text { LRATE does not Granger Cause INF }\end{array}$ & 52 & $\begin{array}{l}0.32414 \\
2.58781\end{array}$ & $\begin{array}{l}0.7248 \\
0.0859\end{array}$ \\
\hline $\begin{array}{l}\text { LOG(REER) does not Granger Cause LRATE } \\
\text { LRATE does not Granger Cause LOG(REER) }\end{array}$ & 52 & $\begin{array}{l}17.2285 \\
0.73871\end{array}$ & $\begin{array}{l}\text { 2.E-06 } \\
0.4832\end{array}$ \\
\hline $\begin{array}{l}\text { GROWTH does not Granger Cause LRATE } \\
\text { LRATE does not Granger Cause GROWTH }\end{array}$ & 52 & $\begin{array}{l}0.26624 \\
4.86701\end{array}$ & $\begin{array}{l}0.7674 \\
0.0120\end{array}$ \\
\hline
\end{tabular}




\begin{tabular}{|c|c|c|c|}
\hline Sample: 2000Q1 2013Q2 & & & \\
\hline \multicolumn{4}{|l|}{ Lags: 2} \\
\hline Null Hypothesis: & Obs & F-Statistic & Prob. \\
\hline $\begin{array}{l}\text { LOG(REER) does not Granger Cause INF } \\
\text { INF does not Granger Cause LOG(REER) }\end{array}$ & 52 & $\begin{array}{l}1.76167 \\
1.04978\end{array}$ & $\begin{array}{l}0.1829 \\
0.3581\end{array}$ \\
\hline $\begin{array}{l}\text { GROWTH does not Granger Cause INF } \\
\text { INF does not Granger Cause GROWTH }\end{array}$ & 52 & $\begin{array}{l}0.50295 \\
1.24195\end{array}$ & $\begin{array}{l}0.6080 \\
0.2981\end{array}$ \\
\hline $\begin{array}{l}\text { GROWTH does not Granger Cause LOG(REER) } \\
\text { LOG(REER) does not Granger Cause GROWTH }\end{array}$ & 52 & $\begin{array}{l}4.03464 \\
2.64905\end{array}$ & $\begin{array}{l}0.0242 \\
0.0813\end{array}$ \\
\hline
\end{tabular}

\subsection{Variance Decompositions}

Untuk memahami sumbangan dari kejutan (shock) kenaikan BI rate dan fund rate dari model empirical maka digunakan analisis variance decomposition. Tabel 3 memperlihatkan bahwa menurut estimasi sistem VAR dalam persamaan (1), inovasi dalam BI rate, $\varepsilon^{\mathrm{d}}$, memberikan sekitar $40 \%$ perubahan dalam variabel agregat dalam ekonomi Indonesia, paling besar adalah inflasi dan REER sekitar 15\%, dan relative rendah pada bunga pinjaman sekitar 5\%, dan pertumbuhan ekonomi sekitar $4 \%$.

\begin{tabular}{l|c|c}
\multicolumn{3}{c}{ Tabel 3 Sumbangan Kejutan (shock) Moneter terhadap } \\
Variance Decompositions \\
\hline BI rate & BI rate & Fund rate \\
\hline Inflasi & $61,1 \%$ & $23,4 \%$ \\
\hline REER & $14,8 \%$ & $4,8 \%$ \\
\hline Bunga pinjaman & $14,6 \%$ & $4,3 \%$ \\
\hline Pertumbuhan & $5,4 \%$ & $12,3 \%$ \\
\hline Sumber: Data diolah & $4,1 \%$ & $12,8 \%$
\end{tabular}

Tabel 3 memperlihatkan bahwa berdasarkan estimasi model VAR persamaan (2), inovasi (kenaikan) dalam fund rate , $\varepsilon^{f}$, memberikan sekitar $58 \%$ perubahan agregat dalam ekonomi Indonesia, paling besar BI rate yaitu sekitar 23\%, kemudian pertumbuhan sekitar 13\%, dan bunga pinjaman sekitar $12 \%$. Sedangkan pengaruh pada inflasi dan REER relatif rendah. Temuan ini mengejutkan karena ternyata kejutan (shock) eksternal lebih besar daripada internal terhadap ekonomi Indonesia. Penjelasannya adalah bahwa ekonomi Indonesia sangat terbuka sehingga kejutan eksternal, dalam hal ini fund rate, berpengaruh besar terhadap aliran modal masuk dan keluar Indonesia. Pengaruhnya juga dirasakan untuk pertumbuhan. 
Model empiris ini bersesuaian dengan model teoritis. Dari model empirkal dengan mempergunakan VAR memperlihatkan bahwa kebijakan menaikkan BI rate berimplikasi pada kenaikan suku bunga pinjaman, penurunan inflasi (dengan lag), penurunan pertumbuhan, dan apresiasi REER (dengan lag) sekalipun untuk hal ini tidak stabil.

Sementara itu, kebijakan moneter bank sentral di luar negeri (dalam hal ini kenaikan Fed fund rate) diikuti oleh kenaikan BI rate, peningkatan bunga pinjaman (dengan lag), peningkatan inflasi, dan apresiasi FEER (setelah 3 triwulan didahului oleh depresiasi).

Hasil studi empiris ini juga bersesuain dengan studi yang dilakukan oleh Uribe an Yue (2006) yang mendapatkan bahwa kejutan (shock) suku bunga AS merupakan 20\% dari pergerakan aktivitas agregat di ekonomi sedang berkembang (Amerika Latin dan Filipina).

\section{KESIMPULAN}

Dari pengamatan (stylized facts), model empiris VAR, dan model teoritikal jelas bahwa kebijakan moneter the fed, dalammenaikkan atau menurunkan fund rate, memberikan pengaruh besar pada ekonomi Indonesia. Kenaikan fund rate diikuti dengan kenaikan BI rate, selanjutnya bunga pinjaman, penurunan inflasi dan pertumbuhan ekonomi dengan penundaan (lag). Penurunan pertumbuhan lebih besar pada saat kenaikan fundrate dan BI rate bersamaan, dibandingkan dengan jika kenaikan hanya pada BI rate saja. Apresiasi REER membutuhkan waktu (lag) dengan didauhului oleh depresiasi. Kebijakan stabilisasi nilai tukar dapat menurunkan inflasi dan memperkuat REER dengan cepat, dan pertumbuhan ekonomi positif. Model teorikal sesuai dengan model empiris VAR, sekalipun terdapat perbedaan dalam kecepatan penyesuaian dan kestabilannya.

Dari model teoretikal yang bersesuain cukup baik dengan model empiris dapat dilakukan excersise dimana penurunan fund rate yang diikuti oleh penurunan BI rate menurunkan bunga pinjaman dan menaikkan pertumbuhan ekonomi, dan apresiasi REER. Namun inflasi juga meningkat. Sedangkan peningkatan produktivitas domestik meningkatkan pertumbuhan lebih tinggi daripada penurunan BI rate, dan inflasi yang menurun serta apresiasi REER. Karena itu kemampauan meningkatkan produktivitas domestik sangat penting tidak saja bagi stabilitas tetapi juga bagi pertumbuhan ekonomi. Sedangkan peningkatan produktivitas di luar negeri berimplikasi negatif terhadap ekonomi domestik yaitu menurunkan pertumbuhan dan depresiasi REER. Sekalipun demikian, inflasi mengalami penurunan. 


\section{DAFTAR PUSTAKA}

Bank Indonesia, 2013, Statistik Ekonomi dan Keuangan Indonesia, dalam http://www. bi.go.id/web/id/Statistik/Statistik+Ekonomi+dan+Keuangan+Indonesia/Versi+HTML/ Sektor+Moneter/, diakses 20 September 2013

Calvo, Guilermo. 1983, "Staggered Prices in a Utility Maximizing Framework", Journal of Monetary Economics, 12:383-398

Gali, Jordi dan Tommaso Monacelli,2005, "Monetary Policy and Exchange Rate Volatility in a Small Open Economy", Review of Economics Studies, 72: 707-734.

Ho, Tai Kuang, 2009, "Derivation of Monacelli (2005) Small Open Economy Model", Manuscript. National Tsing Hua Univerisity, Taiwan.

Martens, Karl, 2013, "Macroeconomic Theory: Money and Output", Manuscript, Cornell University.

Obstsfeld, Maurice. and Rogoff, Kenneth, 2007, Foundations of International Macroeconomics, Cambridge, MA: MIT Press

Uribe, Martin and Vivian Z.Yue, 2006, "Country Spread and Emerging Countries: Who Drives Whom?", Journal of international Economics, 69:6-36.

Vegh, Carlos, 2013, Open Economy Macroeconomics in Developing Countries. Cambridge, MA: MIT Press. 